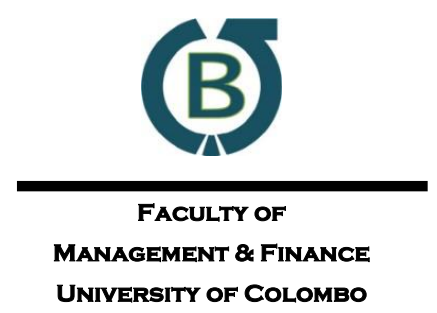

Colombo

Business

Journal

INTERNATIONAL JOURNAL OF

THEORY \& PRACTICE

Vol. 12, No. 01, June, 2021

\title{
Factors Predicting Consumers' Continuance Intention to Use Mobile Wallets: Evidence from Kerala, India
}

\author{
P. Smitha Xavier ${ }^{\mathrm{a}} \bowtie$, Zakkariya K. A. ${ }^{\mathrm{a}}$ \\ ${ }^{a}$ School of Management Studies, Cochin University of Science and Technology, India
}

\begin{abstract}
Mobile wallets are novel and is commanding attention globally as an alternative means of payment. As far as any technology is concerned, continued usage of the system is far more important than its initial adoption, on which prior literature has concentrated upon. The purpose of this study is to examine the factors that predict a mobile wallet user's usage continuance intention. The study, based on a valence framework, analyses the effect of the various dimensions of valence, namely the effect of positive valence (hedonic value, utilitarian value, monetary value and social value) and negative valence (perceived risk) on the usage continuance intention of mobile wallet users in Kerala. Data was collected from 134 participants through a self-administered online questionnaire, and variance based PLS-SEM was used for analysis. The results of the study indicate that both positive and negative valence significantly predicted the usage continuance intention.
\end{abstract}

Keywords: Continuance Intention, Valence Model, Utilitarian Value, Hedonic Value, Mobile Wallets

Received:

05 February 2021
Accepted revised version:

09 June 2021
Published:

30 June 2021

Suggested citation: Xavier, P. S. \& Zakkariya, K. A. (2021). Factors predicting consumers' continuance intention to use mobile wallets: Evidence from Kerala, India. Colombo Business Journal, 12(1), 114-144.

DOI: http://doi.org/10.4038/cbj.v12i1.73

(C) 2021 The Authors. This work is licensed under a Creative Commons Attribution 4.0 International License which permits unrestricted use, distribution, and reproduction in any medium, provided the original work is properly cited.

\smitharesearch1@gmail.com (iD) http://orcid.org/0000-0002-8406-4997 


\section{Introduction}

The advancement in technology has brought in changes as to how people shop and pay for their purchases. With the internet penetration increasing in India, combined with the tremendous surge in the usage of smart phones, people, particularly the millennials, are transforming the way payments are made. There has been an increase in digital transactions with a growth rate of 58.8\% during 2018-2019 as is evident from the various reports of Reserve Bank of India (Reserve Bank of India [RBI], 2019).

The mobile wallet is fairly a recent phenomenon which has gained a lot of popularity with the wide spread use of smart phones. A lot of technological advancements are happening in related fields like mobile commerce and this definitely has increased the scope of the mobile wallets (Au \& Kauffman, 2008). Many of the technological companies like Google, Apple and Samsung, realizing the new business opportunity brought about by the penetration of smart phones and data services, have introduced their own payment platforms to enable users to seamlessly transact in the online environment. According to Merritt (2011), new payment methods like the mobile wallets have substantially grown in popularity across the world during the last decade.

Many studies have been conducted in the realm of mobile-related services, especially mobile-commerce (Ozturk et al., 2016; Yang, 2010), mobile banking (Koenig-Lewis et al., 2010; Riquelme \& Rios, 2010) and mobile payments (Thakur \& Srivastava, 2014; Yang et al., 2015). Among these, most studies that have been conducted on mobile wallets is in the context of adoption intention and its various predictors like perceived ease of use, perceived usefulness and trust, (Chawla \& Joshi, 2019; Shankar \& Datta, 2018), performance expectancy, social influence, promotional benefits (Madan \& Yadav, 2016) and facilitating conditions (Chawla \& Joshi, 2019). However, studies on usage continuance intention of mobile wallet users is equally important but scarce (Hsiao et al., 2016; Lankton et al., 2012; Lee, 2014). This study addresses this research gap and has been conducted to identify the factors that predict the consumers' continued usage intention of mobile wallets in the context of Kerala in India

'Digital India' is a campaign that has been undertaken by the government of India with a grand vision for transforming the country into a digitally empowered economy (Common Service Centres Scheme, 2021). As part of its mission, huge emphasis is laid on the arena of digital payments. The digital scenario of India is rapidly undergoing changes both because of the progressive regulatory policies and 
initiatives by the government to make India a digital economy, and because of the advancements taking place in the technological front. At the same time, the Indian retail sector is also getting transformed and e-commerce is gaining prominence day by day (Competition Commission of India, 2020; India Brand Equity Foundation, 2021). The Indian e-commerce market is among the fastest growing markets in the world (Competition Commission of India, 2020) and this has resulted in tremendous investments from global investors into the E-commerce sector of India. The funding to the e-commerce sector started in 2009 and so far, it has received USD 13,338 million in 904 funding rounds (Competition Commission of India, 2020). Simultaneously, there has been a growth rate of $58.8 \%(2018-19)$ in the total digital transactions in volume terms as against 50.4\% in 2017-18 (RBI, 2019). Some of the most popular major e-wallets are, Paytm, MobiKwik and Oxigen (Bagla \& Sancheti, 2018). In this context, it is very much imperative that we understand the factors that induces a customer to become a regular mobile wallet user, routing his transactions through the mobile wallet.

The aim of this study is to provide insight into factors that predict usage continuance intentions among the users of mobile wallets in Kerala, India. Form a theoretical perspective, this study examines the less widely used theoretical base for predicting the continuance intention - the valence framework - to develop and test a model which is in a better position to predict the intention of the consumer to continue using this emerging technology. In this study, in order to develop the conceptual basis and the research framework, we have relied on literature in similar areas like adoption of m-banking, m-payment services, m-commerce and other mobile services. The study tries to explore how the various values that the consumer derives from the usage of mobile wallets like hedonic value, social value, monetary value and utilitarian value contribute to the continuance intention of the consumer in using mobile wallets.

The paper is structured as follows. The ensuing section provides the review of literature done in the area of mobile wallets and related fields and also contains the proposed research model and the hypotheses development. Then, the methodology is elaborated. Thereafter, the results of the analysis are presented. The paper concludes with a discussion of findings and implications of the study both for practice and theory.

\section{Literature Review and Hypotheses Development}

Mobile wallets are the same as physical wallets - but in the digital form. A mobile wallet can be used to make payments at physical stores, online stores, to transfer money among accounts, to make bill payments and many other uses. In India, mobile 
wallets come under the classification of pre-paid Instruments. There are many variants of mobile wallets-namely open wallets, closed wallets and semi-closed wallets. An open mobile wallet is one which allows the user to pay digitally, transfer funds and even withdraw the cash using an Automatic Teller Machine (ATM). Closed mobile wallets, on the other hand, are issued by specific companies (retailers) to facilitate digital transactions with that company alone. They cannot be used anywhere else nor do they allow withdrawal of cash at ATMs. Sometimes these retailers may have contractual agreements with a number of other companies and if so, the user can use the mobile wallet at their outlets as well. Such mobile wallets are termed as semiclosed mobile wallets. Money can be loaded into the mobile wallet via credit cards or bank accounts using debit cards or the internet banking facility.

Many studies have been conducted to understand the factors that predict adoption intention for mobile wallets. Numerous studies have been conducted by using the Technology Acceptance Model (TAM) framework to explore the importance of perceived usefulness and perceived ease of use in influencing attitude and thereby adoption intention in much related areas like mobile phone services, mobile banking and mobile wallets (Alalwan et al., 2016; Bailey et al., 2017; Islam et al., 2013). Madan and Yadav (2016) found that performance expectancy, effort expectancy, perceived value and perceived risk influenced the behavioural intention to adopt mobile wallets. Shin (2009) explored the key factors that drive the acceptance of mobile wallets by extending the Unified Theory of Acceptance and Use of Technology (UTAUT) framework to include trust and security. Another study was conducted by Chen and Chang (2013) in a related area namely Near Field Communications (NFC) and found that performance expectancy and social influence positively influenced the consumers' attitude towards NFC.

On reviewing literature, it was found that_usage continuance intention has been studied in the context of mobile shopping (Groß, 2016), mobile hotel booking technology (Ozturk et al., 2016), information technology (Deng et al., 2010) and mobile banking (Albashrawi \& Motiwalla, 2019), but not in relation to mobile wallets. Understanding the importance of usage continuance intention in the context of mobile related services, this study has extended the concept to the context of mobile wallets.

\section{Continuance Intention}

Prior Literature has established the fact that retention of an existing user is five times cheaper than the acquisition of a new user (Reichheld \& Schefter, 2000; Bhattacherjee, 2001a; Nataraj \& Rajendran, 2018) and this is especially true in the 
case of services industry. In the case of information systems, the continued use of the technology is of extreme importance for success, more than their initial adoption (Zheng et al., 2013; Zhou, 2013; Zhou et al., 2018) as this builds loyalty (Bitner et al., 2002). The facilitation of continuance intention is especially critical, particularly in a scenario characterised by low switching costs. Thus, for mobile wallet providers, continuous usage of the user is a must for their sustenance. The long-term sustainability of mobile wallets and its ultimate success depends on the continuing use rather than on just the initial adoption (Bhattacherjee, 2001b).

It is important to study continuance intension as a separate phenomenon as continuance intention cannot be viewed to be just an extension of the adoption intention (Limayem et al., 2007). The literature available on the key determinants of continued use in the area of mobile applications is scant (Hsiao et al., 2016; Lankton et al., 2012; Lee, 2014). Hence it is imperative that we look more closely at the users' behaviour post-adoption of the mobile wallet. Therefore, the objective of the study is to throw light on the factors that affect consumers' continuance intention of using mobile wallets.

In order to examine this phenomenon, this study utilizes the Valence theory. Customer intentions may be explained by the valence framework which considers both the positive and negative aspects of behavioural beliefs (Peter \& Tarpey, 1975) that could influence intentions. As per the theory, the consumer enjoys a net positive valence when the benefits exceed the costs of using a product, consequently resulting in higher adoption intention (Chin et al., 2020). In the case of mobile payments, the valence is the net of perceived benefits (like time saving, convenience etc.) and perceived costs (risk) and if the benefits outweigh the risks, it will result in adoption (Chin et al., 2020). Valence theory has also been used to predict repeated purchase intentions in the context of e-commerce (Mou et al., 2017). This may be extended to mobile wallet usage continuance intention as well. When the consumer perceives a net positive valence, he will continue to use the mobile wallet.

\section{Valence Theory}

A significant percentage of the research conducted in the area of mobile wallets has used the theoretical foundations of TAM (Slade et al., 2015). Other theories that have been used in the context of mobile payments are the Diffusion of Innovation theory (Arvidsson, 2014), uncertainty-risk-value framework (Yang et al., 2015), and extensions of the TAM (Bailey et al., 2017; Matemba \& Li, 2018; Shaw, 2014). However, the concept of value to the user is of much importance especially in the case of new technologies (Kim et al., 2007). This study therefore uses the valence 
framework, which is derived primarily from the fields of psychology and economics (Goodwin, 1996). The valence framework incorporates both benefits and risk and helps us to understand how they can simultaneously affect behaviour as propounded in the seminal paper by Peter and Tarpey (1975). They emphasised that the decision making process of a consumer is determined by the benefits and risks he or she perceives to be present in the product. The consumer always behaves in a manner that would minimize the risk but at the same time would behave in a manner that would increase the perceived benefits of using the product or service (Kim et al., 2000; Peter $\&$ Tarpey, 1975). By taking both into consideration, the consumer will ultimately behave in a manner that would maximize his or her net valence. The valence model has previously been used in the context of mobile payments (Lu et al., 2011) and in online shopping (Kim et al., 2008).

Though it is a valid framework for research in the e-commerce context, the valence framework needs to be extended or changed to capture attributes especially relevant to the mobile environment (Lu et al., 2011). Hedonic value and utilitarian value are two of the most commonly discussed dimensions of consumer value in the literature (Overby \& Lee, 2006). A typology of consumer value presented in a seminal work (Holbrook, 1999) also includes as aspects of utility (efficiency \& excellence) and hedonic (aesthetics \& play) value. These two value dimensions have also been discussed in relation to mobile technology (Chemingui \& Ben lallouna, 2013; Chun et al., 2012; Ozturk et al., 2017; Yang \& Lee, 2010; Yang, 2010). Holbrook (1999) also discusses social value (status \& esteem), and it is discussed in the technology literature as well (Pura, 2005; Shin, 2009; Yang et al., 2012; Zhou et al., 2010). In addition to these commonly used value dimensions, literature on technology consumption (especially internet and mobile services) discusses monetary value (Pura, 2005; Madan \& Yadav, 2016). Finally, perceived risk is a much-discussed area in relation to the adoption of mobile and internet technologies (see for example, Gao \& Waechter, 2017; Keith et al., 2015; Yang, 2013). It represents negative valance although negative valence seems to be absent in most discussions of value in consumer value literature. In the mobile environment, we thus postulate that positive valence is generated by the attributes of the mobile wallets such as the hedonic attributes, social, monetary and the utilitarian attributes whereas negative valence is brought about by perceived risk.

\section{Hedonic and Utilitarian Value of Mobile Wallets}

The hedonic aspects refer to the attributes that bring in an element of "fun and enjoyment" for the user (Babin et al., 1994) and in general terms, hedonic motivation 
relates to the pleasure or fun derived from using a product or service. Moreover, hedonic motivation has proved to play an important role in technology use (Brown \& Venkatesh, 2005). Though the concept of hedonism related to technology use was introduced in UTAUT 2 model (Venkatesh et al., 2012), prior researchers have shown it to be an important predictor of adoption of technology related products like word processing and graphics programs (Davis et al., 1992) and microcomputer usage (Igbaria et al., 1995). It has been studied in various forms like perceived enjoyment, hedonic performance expectancy and hedonic value. It has been studied as perceived enjoyment in the context of predicting mobile payment adoption (Chemingui \& Ben lallouna, 2013) and usage continuance intention of information systems (Magro et al., 2013). Hedonic performance expectancy is a critical determinant of mobile shopping services adoption (Yang, 2010) and hedonic value is found to be a driving force in the usage of mobile data services (Yang \& Lee, 2010). Thus, it follows that the mobile wallet users too, derive enjoyment or hedonic value when using this technology, just as they do in using any information systems related services. Hence, we propose that hedonic value gives positive utility and arrive at the following hypothesis:

$\mathrm{H}_{1}$ : The hedonic value has a positive influence on the mobile wallet user's continuance intention.

Utilitarian benefits are those contributed by attributes that help in the functionality (Babin et al., 1994) or the basic use of a mobile wallet. The consumers derive a utilitarian value when they are able to meet their objectives hassle-free, and this holds true in the case of services (Jones et al., 2006). In the literature on technology use, especially in the realms of information systems and mobile related services, this aspect has been conceptualised as usefulness. Utilitarian value, in its various forms like usefulness, ease of use, convenience and utilitarian performance expectancy, has been studied in the context of mobile banking (Alalwan et al., 2016; Riquelme \& Rios, 2010), mobile networks (Akter et al., 2013; Sun et al., 2014; Zhou, 2013), adoption of smartphones (Chun et al., 2012), mobile-commerce (Wu \& Wang, 2005), online shopping (Chiu et al., 2014), mobile devices (Park \& Yang, 2006) and mobile data services (Yang \& Lee, 2010). The ubiquitous nature of mobile wallets offers utilitarian value in the form of flexibility and ease of use, time savings and convenience (Kleijnen et al., 2007). Thus, the utilitarian attributes are usefulness, ease, time and place convenience, due to the advantage of mobility and ubiquity. Hence, we propose that utilitarian value positively affects continuance intention by giving positive utility to the user and arrive at the following hypothesis:

$\mathrm{H}_{2}$ : The utilitarian value has a positive influence on the mobile wallet user's continuance intention. 


\section{Monetary Value}

Monetary promotions are generally evaluated as attractive by consumers (Buttner et al., 2015). Customers attain monetary value through promotions like cash backs (Ballestar et al., 2016; Vana et al., 2018), cash discounts, coupon codes, mobile coupons (Thakur, 2016), and location-based geo-coupons (Lariviere et al., 2013), and these promotions positively affect the adoption intention of mobile wallet services (Madan \& Yadav, 2016). Campbell and Diamond (1990) found that consumers notice monetary promotions even when their magnitude is small. Mobile wallets offer many sales promotions in the form of cash backs and discounts and these can bring in perceptions of monetary savings (Blattberg \& Neslin, 1990). Thus, it follows that customers derive a monetary value from the usage of mobile wallets. This monetary value that is derived can positively influence the continued usage of mobile wallets and hence the following hypothesis is proposed:

$\mathrm{H}_{3}$ : The monetary value has a positive influence on the mobile wallet user's continuance intention.

\section{Social Value}

Social Value refers to the social benefits attained on using a product or service and it is obtained when the user is able to project an image or an enhanced social selfconcept (Sweeney \& Soutar, 2001) that is congruent with the set standards of his reference groups, thus being able to feel connected with them (Aulia et al., 2016). Mobile applications on smartphones have attained wide popularity in emerging nations (Mehra et al., 2020). The young generation, born after 1993 and onwards, has been brought up in the world of internet and they adopt mobile phones and mobile applications on the influence of friends to gain social acceptance among their peers and thus derive social value (Zolkepli et al., 2020). Prior studies have studied related concepts like subjective norms and social influence, which are normative beliefs that are thrust upon a person, by the people whom one considers important- friends, family members and relatives (Riquelme \& Rios, 2010). This is especially true in the case of adoption of new technologies (Venkatesh \& Davis, 2000; Young \& Kent, 1985) like mobile services (Nysveen et al., 2005), mobile learning (Wong et al., 2012) and mobile payment services (Yang et al., 2012). Thus, we postulate that social value is an important determinant of usage continuance intention and arrive at the following hypothesis:

$\mathrm{H}_{4}$ : The social value has a positive influence on the mobile wallet user's continuance intention. 


\section{Figure 1: Conceptual Model}

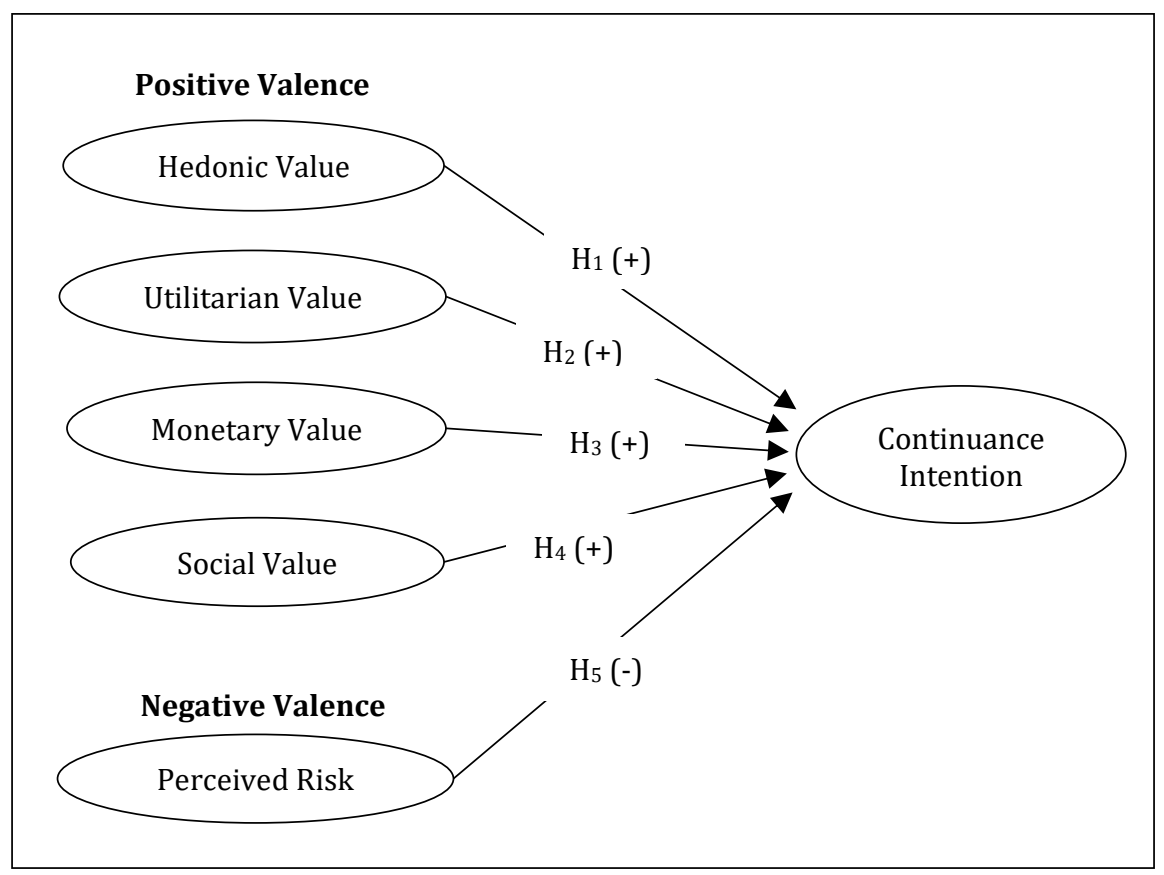

\section{Perceived Risk}

Past studies have demonstrated that perceived risk is a strong deterrent of eservices adoption intention (Featherman \& Pavlou, 2003). Amoroso and MaginerWatanabe (2012) found that behavioural intention in internet-related technologies like mobile banking and mobile wallets are influenced by perceived risk and the perception of security. Yang et al. (2015) have also attempted to understand the concept of perceived risk and how it affects mobile payments.

In the case of mobile payment services, customers expect the service providers to protect their privacy by not sharing or distributing their private information to other parties. Customers are often worried that their personal information would be collected by mobile payment systems and shared with other entities (Keith et al., 2015). If the customer perceives a breach with respect to this regard, then he would perceive a greater risk in using their products or services (Gao \& Waechter, 2017). This could apply to mobile wallets as well. Another aspect which often contributes to perceived risk is the use of mobile wallet as a medium of financial transaction similar to the case of online transactions (Yang, 2013). Yang (2013) found that internet users are reluctant to do online transactions on account of perceived risk. The greater degree of uncertainty and risk associated with erroneous transactions, absence of transaction 
records and fraudulent practices is more prevalent in online transactions as compared to offline transactions (Mallat, 2007; Zhou, 2013). Thus, it follows that consumers perceive mobile wallets to be riskier when compared to offline transactions. First, it is related to how secure the medium is for doing financial transactions and second, they are also concerned about the information that is stored in the wallets. Thus, perceived risk brings about a negative valence and thereby we come to the following hypothesis:

$\mathrm{H}_{5}$ : Perceived risk has a negative influence on the mobile wallet user's continuance intention.

Based on all of the above hypotheses, the conceptual model framed is shown in Figure 1. With the constructs hedonic value, social value, monetary value, utilitarian value, perceived risk and continuance intention, the model is tested in the succeeding sections.

\section{Methodology}

\section{Measures}

In the survey, multi-item scales were used to measure all the hypothesised constructs and these measures were adapted from prior literature after appropriate modification. The scales were originally used in the context of mobile payments, near field communication based mobile payment technology, mobile services and in other similar areas. The wording of questions was modified to include mobile wallets to suit the present study. The scales used are given in the Appendix 1. Hedonic Value (HV) was measured using the three-item scale from Oliveira et al. (2016). Utilitarian Value (UV) was measured with the scales developed by Ozturk et al. (2017). The scale used the attributes of utilitarian and convenience value containing five items related to convenience, usefulness and time saving. Monetary Value (MV) was measured using the scale comprising of three items from Chandon et al. (2000). For measuring social value, this study used the Pura (2005) social value scale comprising of three items. Perceived Risk was conceptualised as comprising of security concern and was measured using three item scale from Koenig-Lewis et al. (2015). Continuance Intention in using the mobile wallet was measured using the scale from Zhu and Chang (2014) comprising of three items. All of the items were measured on a five-point Likert scale (ranging from $1=$ strongly disagree to $5=$ strongly agree). To pre-test the instrument, a pilot study was conducted among 30 subjects who were users of mobile wallet and mobile payment services. All scales were checked for reliability and Cronbach's Alpha was found to be over and above the acceptable value of 0.7 (Bagozzi \& Yi, 1988). 
A web-based survey was used to collect the data from the users of mobile wallets. The study used convenience sampling. Convenience sampling was used as the population was not finite. However, to ensure that only people who used mobile wallets responded to the questionnaire, a screening question was included. Only those who had used mobile wallets were included in the study. The data was collected from people across Kerala. The language used was simple and in English and to ensure the questions are properly understood by the respondents, a pilot study was done. Kerala is a state with a high literacy rate. The profile of the respondents is more or less uniform throughout the state and hence a relatively small sample was found to be adequate for the study.

The respondents were all users of mobile-wallets or any mobile payment service and had used the service at least once in the past one month. The web-based survey elicited a total of 150 responses. This data was then scrutinized for missing values and ultimately, a total of 134 responses were used for the analysis. In the study, the age of the participants ranged from 18 years to 55 years and the average age was 22 years. Of the participants, $56 \%$ were males and $44 \%$ females. Most of the participants $(63 \%)$ were pursuing postgraduate courses. The remaining participants $(37 \%)$ had completed their postgraduate education; these were mostly employed in government sector and public limited companies $(75 \%)$ while a few ran their own enterprises (25\%). Most of the participants used multiple accounts and it was found that that $85 \%$ liked Google Pay, followed by Paytm (79\%), PhonePe (58\%) and Amazon Pay (35\%). Most participants, (almost 71\%) used the mobile wallets on a daily or weekly basis. The major uses for which the transactions were made were towards mobile recharge, bill payments and for booking movie tickets. However, a surprisingly large number used it for transferring money to their friends and peers. It was also found that only $54 \%$ used their wallets to store loyalty cards, gift cards and coupons. Most participants used their savings bank account to load the wallets (50\%). Another popular means of loading the mobile wallets was by using debit cards (57\%). The average amount per transaction using the mobile wallet was Indian Rs. 681.

We have used Partial Least Square - Structural Equation Modelling (PLS-SEM) for the analysis which is included in the same class of models as CB-SEM- and which allows estimating multivariate cause-effect relationships involving latent variables (Richter, Cepeda Carrión et al., 2016). So far, by reviewing literature, it is found that PLS-SEM has been successfully applied to different contexts in the social sciences research like marketing (Hair, Sarstedt, Ringle \& Mena, 2012), tourism (do Valle \& Assaker, 2016), international management (Richter, Sinkovics et al., 2016), and 
strategic management (Hair, Sarstedt, Pierper, \& Ringle, 2012). The focus of PLSSEM is on the explanation of variances and this makes it a prediction-oriented approach to SEM (Shmueli et al., 2016). The use of PLS-SEM is particularly effective when the assumed cause-and-effect relationships have not been sufficiently explored in prior studies, and when the model involves complex constructs measured formatively or reflectively (Hair et al., 2017; Rigdon, 2016; Sarstedt et al., 2016). Moreover PLS-SEM converges with smaller samples and in such circumstances, it can be relied upon to obtain valid results. The prediction orientation of this study coupled with the small sample size (sufficient for the near homogenous data) and the complexity of the model involving latent constructs substantiates the use of variance based PLS-SEM. WarpPLS v 6.0 was used for the testing of the hypotheses.

\section{Data Analysis and Results}

The analysis of data comprised of several steps. It began with the initial screening of the data, following which the data was checked for normality using the descriptive statistics. This is followed by measurement model analysis and the structural model analysis. The purpose of measurement model analysis is to establish the validity of the scales used for measurement of the constructs, while the structural model analysis tests the hypotheses. The results obtained from all these analyses are elaborated below.

\section{Initial Screening}

The raw data collected was initially screened for missing values using IBM SPSS 23 and all the subsequent analyses were done using WarpPLS v 6.0 statistical software. The data was first examined using descriptive statistics which are reported in Table 1.

Table 1: Descriptive Statistics

\begin{tabular}{lrrrr}
\hline Variable & Mean & SD & Kurtosis & Skewness \\
\hline HV & 3.72 & 0.83 & 0.359 & -0.552 \\
UV & 4.40 & 0.55 & -0.318 & -0.714 \\
MV & 3.90 & 0.65 & -0.897 & 0.311 \\
SV & 3.12 & 1.00 & -0.960 & -0.910 \\
PER_RISK & 2.86 & 0.92 & -0.027 & 0.073 \\
CONT_INT & 4.27 & 0.67 & 0.210 & -0.732 \\
\hline
\end{tabular}

Note: HV: Hedonic Value; UV: Utilitarian Value; MV: Monetary Value; SV: Social Value; PER_RISK: Perceived Risk; CONT_INT: Continuance Intention. 
The proposed set of hypotheses were tested using a two-step modelling approach following Anderson and Gerbing (1988). First the measurement model was assessed to confirm the psychometric properties of the constructs, after which the hypotheses were tested through the structural model.

\section{Measurement Model Analysis}

This section presents the narration of the following steps of analysis: First the adaptability of the scales to the study was checked using Exploratory Factor Analysis (EFA) and Confirmatory Factor Analysis (CFA). After this, the internal validity was established through Cronbach's Alpha. The KMO and Bartlett's Test was used to establish adequacy of the sample size and sufficient correlation among the factors for conducting factor analysis. In the next step, the internal consistency was established following which, the measurement model was analysed for convergent and discriminant validity. Then the hypotheses were tested through the structural model analysis.

\section{EFA, CFA and Sampling Adequacy}

The measurement model was evaluated using EFA and CFA. On conducting EFA, two items of the utilitarian scale were deleted due to lack of sufficient loadings. To confirm the suitability of the scales for the context of mobile wallets, EFA was performed. The results of The Kaiser-Meyer-Olkin Test was 0.780, above the required 0.7 and hence proved sampling adequacy. The Bartlett's Test of Sphericity was significant at $p<0.000$ and it indicated sufficient correlation among the factors for conducting factor analysis (Hair et al., 1998). The factors with eigen value greater than 1 were extracted and accounted for $69.7 \%$ of the variance. CFA was carried out and the internal consistency reliability was established through the measurement of Cronbach's Alpha, composite reliability and average variance extracted. The values of Cronbach's Alpha for the constructs Hedonic Value (0.83), Utilitarian Value (0.83), Monetary Value (0.81), Social Value (0.897, Perceived Risk (0.83) and Continuance Intention (0.88) were all found to be over and above the acceptable value of 0.7 (Bagozzi \& Yi, 1988).

\section{Establishing Convergent and Discriminant Validity}

The measurement model was analysed for convergent and discriminant validity. Composite Reliability (CR) and the Average Variance Extracted (AVE) were used to assess convergent validity (Fornell \& Larcker, 1981). In this study, the composite reliability ranged between 0.88 and 0.94 (Table 2), well above the recommended level of 0.7 (Gefen et al., 2000). The AVE ranged from 0.59 to 0.83 , thus meeting the 
recommended level of 0.5 (Hair et al., 2010). The discriminant validity was tested by comparing the square root of the variance extracted for a construct and the correlation between constructs (Fornell \& Larcker, 1981). As prescribed, it was found that the square root of AVE for each of the latent variables exceeded the interconstruct correlations, and thus the condition for discriminant validity has been met. The results are exhibited in Table 3. Also, results of the variance inflation factor (VIF) (see Table 2) were in the range of 1.06 to 1.57 , below the recommended level of 5 (Hair et al., 2010). Thus, the validity and reliability of the measurement model is established. The problem of the existence of multicollinearity was also checked using the Full Collinearity Variance Inflation Factor (AFVIF). The value was found to be much lower than the threshold limit of 3.30, thus ruling out the possibility of multicollinearity (Kock, 2012).

Table 2: Measurement Model Statistics

\begin{tabular}{lcccccc}
\hline Factor & Type & Items & $\begin{array}{c}\text { Cronbach's } \\
\text { Alpha }\end{array}$ & CR & AVE & VIF \\
\hline HV & Reflective & 3 & 0.83 & 0.89 & 0.74 & 1.28 \\
UV & Reflective & 5 & 0.83 & 0.88 & 0.59 & 1.51 \\
MV & Reflective & 3 & 0.81 & 0.89 & 0.72 & 1.39 \\
SV & Reflective & 3 & 0.89 & 0.94 & 0.83 & 1.17 \\
PER_RISK & Reflective & 3 & 0.83 & 0.90 & 0.75 & 1.06 \\
CONT_INT & Reflective & 3 & 0.88 & 0.93 & 0.81 & 1.57 \\
\hline
\end{tabular}

Table 3: Inter-Construct Correlations

\begin{tabular}{lrrrrrr}
\hline & HV & UV & MV & SV & PER_RISK & CONT_INT \\
\hline HV & $\mathbf{0 . 8 6 3}$ & & & & & \\
UV & 0.378 & $\mathbf{0 . 7 7 0}$ & & & & \\
MV & 0.193 & 0.425 & $\mathbf{0 . 8 4 9}$ & & & \\
SV & 0.225 & 0.14 & 0.309 & $\mathbf{0 . 9 1 0}$ & & \\
PER_RISK & -0.097 & -0.12 & -0.053 & 0.022 & $\mathbf{0 . 8 6 5}$ & \\
CONT_INT & 0.394 & 0.483 & 0.404 & 0.251 & -0.219 & $\mathbf{0 . 9 0 1}$ \\
\hline
\end{tabular}

Note: The square roots of AVEs are shown in bold on the diagonal. These values must be higher than the inter-construct correlations shown below the diagonal for establishing adequate discriminant validity.

\section{Structural Model Analysis}

First, since the data for all the variables were collected from a single source and at the same time, the presence of common method bias was checked using Harman's 
single-factor test (Podsakoff et al., 2003) to verify if a single factor accounted for majority of covariance among the measures. The test results confirmed the absence of common method bias as the results showed only $23 \%$ of variance for a single factor. The next step was to analyse whether the data fitted the proposed model. This was tested using the variance based PLS-SEM) with the statistical software WarpPLS v 6.0 (Kock, 2012). The results of the testing are exhibited in Table.4.

Table 4: Fit Indices

\begin{tabular}{|c|c|c|}
\hline Fit Index & Value & Threshold Limit \\
\hline $\begin{array}{l}\text { Average path coefficient } \\
\text { (APC) }\end{array}$ & $0.188(p<0.001)$ & $p<0.001$ \\
\hline Average R-squared (ARS) & $0.394(p<0.001)$ & $p<0.001$ \\
\hline $\begin{array}{l}\text { Average adjusted R-squared } \\
\text { (AARS) }\end{array}$ & $0.371(p<0.001)$ & $p<0.001$ \\
\hline Average block VIF (AVIF) & 1.3 & acceptable if $\leq 5$, ideally $\leq 3.3$ \\
\hline $\begin{array}{l}\text { Average full collinearity VIF } \\
\text { (AFVIF) }\end{array}$ & 1.33 & acceptable if $\leq 5$, ideally $\leq 3.3$ \\
\hline Tenenhaus GoF (GoF) & 0.54 & $\begin{array}{c}0.1 \leq \text { small } \leq 0.25 \leq \text { medium } \\
\leq 0.36 \leq \text { large }\end{array}$ \\
\hline $\begin{array}{l}\text { Sympson's paradox ratio } \\
\text { (SPR) }\end{array}$ & 1 & acceptable if $\geq 0.7$, ideally $=1$ \\
\hline $\begin{array}{l}\text { R-squared contribution ratio } \\
\text { (RSCR) }\end{array}$ & 1 & acceptable if $\geq 0.9$, ideally $=1$ \\
\hline $\begin{array}{l}\text { Nonlinear bivariate causality } \\
\text { direction ratio (NLBCDR) }\end{array}$ & 1 & acceptable if $\geq 0.7$ \\
\hline $\begin{array}{l}\text { Statistical suppression ratio } \\
\text { (SSR) }\end{array}$ & 1 & acceptable if $\geq 0.7$ \\
\hline
\end{tabular}

An overall goodness-of-fit (GoF) index was used to establish the adequacy of the hypothesized model. The value of the GoF index is given by the square root of the product of the AVE and average $\mathrm{R}^{2}$. It is found that the GoF index with values of $0.100,0.250$, and 0.360 correspond to small, medium, and large effect sizes, respectively (Tenenhaus et al., 2005). The fit indices are exhibited in detail in Table 4. All the fit indices are within the threshold limits.

The relationship existing between the latent variables, as expressed in the research model, is represented by the structural model. The structural model is assessed by using four criteria, namely Coefficient of Determination $\left(\mathrm{R}^{2}\right)$, predictive 
relevance $\left(\mathrm{Q}^{2}\right)$, effect size and path coefficient $(\beta)$. As per Chin and Newsted (1999), the effect on the endogenous variables is found to be substantial, moderate or weak if the $\mathrm{R}^{2}$ values are $0.67,0.33$ and 0.19 respectively. The predictive validity in connection with a latent endogenous variable is acceptable if the value of Q-squared coefficient is greater than zero. In this study we can see from Table 5 that the Qsquared coefficient is greater than zero and the value of $\mathrm{R}^{2}(0.39)$ indicates the moderate influence on the endogenous variable.

Table 5: $\mathbf{R}^{2}$ and $\mathbf{Q}^{2}$ Coefficients

\begin{tabular}{lc}
\hline Endogenous Construct & Continuance Intention \\
\hline Q-squared & 0.41 \\
R-squared & 0.39 \\
\hline
\end{tabular}

The path coefficients are presented in Figure 2.

\section{Figure 2: Path Coefficients for Continuance Intention}

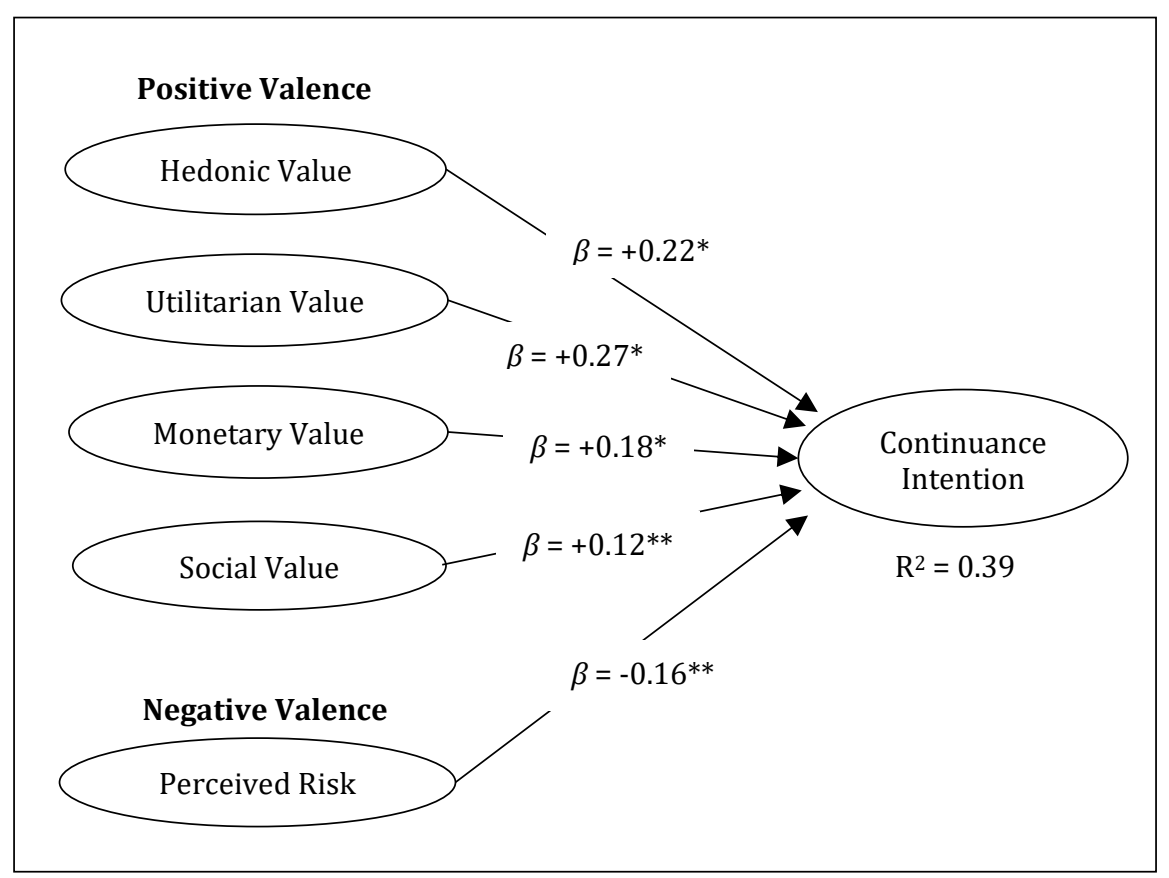

Note: $*$ and $* *$ denote significance levels $p<0.01$ and $p<0.05$, respectively.

As hypothesised, hedonic value, utilitarian value, monetary value and social value, all have a significant positive influence and perceived risk has a significant 
negative influence on the intention to continue using mobile wallet services. As seen from the results (Figure 2) the utilitarian value had the strongest influence on continuance intention $(0.27, p<0.01)$ followed closely by hedonic value $(0.22, p<$ $0.01)$. Further, monetary value $(0.18, p<0.01)$ and social value $(0.12, p<0.05)$ also had a positive influence on continuance intention. It was also found, as hypothesised, that perceived risk had a significant negative influence on continuance intention $(0.16, p<0.01)$.

\section{Discussion and Implications}

The study revealed a lot of insights. it explains the importance of the utilitarian value creation in mobile wallet and other mobile payment services and how this value is instrumental in the usage continuance intention. The utilitarian value is derived from the ease provided by mobile wallets in making payments, in addition to the time and place convenience that they offer. The importance of utilitarian value has also been established by studies in mobile related context (Chun et al., 2012; Park \& Yang, 2006; Wu \& Wang, 2005) and in studies conducted in similar contexts like NFC payments (Ozturk et al., 2017). The positive influence of hedonic value on the usage continuance intention of the mobile wallet users identified in the study is also in accordance with the results of prior studies. Hedonic value derived from perceived enjoyment in using technology products and services, has been identified in the context of technology use (Dabholkar \& Bagozzi, 2002), mobile internet (Cheong \& Park, 2005) and mobile shopping services (Yang, 2010). The study also found that social value has a significant influence on the usage continuance intention of consumers. The significance of social value, i.e., the feeling of acceptance and social approval from peers who used mobile wallet services, has been found in similar contexts like mobile-ticketing service adoption (Mallet et al., 2008) and mobile commerce (Wei et al., 2009; Chong et al., 2012). According to the findings, it also appears that customer derive monetary value on account of promotions via mobile wallets, and this has a positive influence on the continuation intention. This is in accordance with the results of prior studies that show that consumers value monetary benefits like cash backs (Ballestar et al., 2016) and find monetary promotions attractive (Buttner et al., 2015). Earlier researchers have studied perceived risk in the context of adoption of new mobile technologies like mobile banking (Akturan \& Tezcan, 2012; Cruz et al., 2010; Hanafizadeh et al., 2014) and found it to be an impediment to adoption. This study has furthered the relevance of perceived risk to continuance intention as well and found that it has a significant negative impact on continuance intention. 


\section{Theoretical Implications}

This research makes several theoretical contributions. Most of the prior work in the area has used technology models like TAM, TAM 2, UTUAT and UTAUT 2 to study the acceptance of mobile wallets and mobile payment applications and they have concentrated primarily on instrumental beliefs like perceived ease of use, facilitating conditions, performance expectancy, perceived usefulness, and effort expectancy. This study tried to provide more insights from the perspective of value to the consumer, on which literature is scant. The dimensions of value are multi fold - utilitarian, hedonic, monetary and social - all of which have an impact on continuance intention. In this regard, the research made an attempt to study these dimensions, which have so far been almost unexplored in the context of mobile wallet usage, and found them to have a significant influence on consumers' intention to continue usage.

\section{Practical Implications}

The findings of the study have important practical implications for mobile wallet providers. The concepts of e-servicescape (Teng et al., 2018) in the context of internet retailers and $\mathrm{m}$-servicescape in increasing engagement in the context of hotel mobile apps (Lee, 2018) can be applied to mobile wallets as well, especially with respect to the design aspects. The utilitarian performance and hedonic attributes of mobile wallets must be enhanced through better design aspects related to ease of navigation, layout and functionality, which are dimensions of m-service scape (Lee, 2018). These, in turn, save time and help to complete the financial transactions efficiently. Another design aspect of m-servicescape, namely the aesthetic appeal (Lee, 2018), can contribute to the hedonic experience. The hedonic experience and monetary value may also be enhanced by inclusion of fun components like animated tools and inclusion of gamification strategies involving monetary incentives (Bitrian et al., 2021; Hofacker et al., 2016), respectively. Such features can be used by the companies to increase stickiness and loyalty. The study has found that the effect of social value on continuance intention is significant. Social value can also be increased by adding more features for peer-to-peer lending. Undertaking financial transactions over mobile wallets is perceived as risky by users. Perceived risk to a great extent can be mitigated, or in other words, consumers can be made more tolerant towards risk by educating them about the safety measures adopted in mobile wallets. It has been found by researchers in the area of investments that financial literacy can make investors more risk tolerant (Kanagasabai \& Aggarwal, 2020). The same concept can be used and effort may be undertaken to educate consumers regarding the safety measures inbuilt in mobile payment transactions. 


\section{Conclusion}

In this study utilitarian, hedonic and monetary and social values were found to impact on the continuance intention of consumers using mobile wallets. Utilitarian value was found to be valued the most and it had the most significant impact on continuance intention. Another important factor was the hedonic value that consumers derived out of using mobile wallets. Its impact on continuous intention was significant and hence incorporating more hedonic elements into mobile wallets would increase stickiness. The third influencing factor, monetary value, can be enhanced by providing incentives through gamification and also tie-ups with retailers. Social value derived from the usage of mobile wallets also significantly affected the continuance intention. Incorporating elements of fun and providing for more social facilitation and peer to peer lending services can, therefore, enhance the continued usage of mobile wallets.

The study offers several opportunities for further research. This was a crosssectional study and perhaps a longitudinal study would be more apt to test our model since mobile wallets and other similar payment services are still in the initial stages. A longitudinal study would capture the changes when consumers have had an increased awareness and experience with such services. More studies may be conducted to explore the different facets of social value contributed by mobile wallets. For example, it has been found that the interaction design and the infrastructure involved in the payment technology can drive social interactions (Ferreira \& Perry, 2019). Mobile wallets and payment services, especially social payment services like Venmo that facilitate features like peer-to-peer lending, bill splits and other similar features, bring in elements of social engagement (Acker \& Murthy, 2020) and this is something that needs to be further researched in depth. Hedonic aspects of technology products tend to increase engagement and thereby continuance intention. Further studies could be done along these lines as well. Since this study found that monetary value could impact continuance intentions, another aspect which future studies may explore is the effect of promotions to examine the relative importance of impact of those providing both monetary and non-monetary rewards of sales promotions on the usage continuance intention.

\section{Declaration of Conflicting Interests}

The authors declared no potential conflicts of interest with respect to the research, authorship, and publication of this article. 


\section{References}

Acker, A., \& Murthy, D. (2020). What is Venmo? A descriptive analysis of social features in the mobile payment platform. Telematics and Informatics, 52. https://doi.org/10.1016/j.tele.2020.101429

Akter, S., Ray, P., \& D’Ambra, J. (2013). Continuance of mHealth services at the bottom of the pyramid: The roles of service quality and trust. Electronic Markets, 23(1), 29-47. https://doi.org/10.1007/s12525-012-0091-5

Akturan, U., \& Tezcan, N. (2012). Mobile banking adoption of the youth market: Perceptions and intentions. Marketing Intelligence \& Planning, 30(4), 444-459. https://doi.org/10.1108/02634501211231928

Albashrawi, M., \& Motiwalla, L. (2019). Privacy and personalization in continued usage intention of mobile banking: An integrative perspective. Information Systems Frontiers, 21(5), 1031-1043. https://doi.org/10.1007/s10796-017-98147

Alalwan, A. A., Dwivedi, Y. K., Rana, N. P. P., \& Williams, M. D. (2016). Consumer adoption of mobile banking in Jordan: Examining the role of usefulness, ease of use, perceived risk and self-efficacy, Journal of Enterprise Information Management, 29(1), 118-139, https://doi.org/10.1108/JEIM-042015-0035

Amoroso, D. L., \& Maginer-Watanabe, R. (2012). Building a research model for mobile wallet consumer adoption: The case of mobile Suica in Japan. Journal of Theoretical and Applied Electronic Commerce Research, 7(1), 94-110. https://doi.org/10.4067/S0718-18762012000100008

Anderson, J. C., \& Gerbing, D. W. (1988). Structural equation modelling in practice: A review and recommended two-step approach. Psychological Bulletin, 103(3), 411-423. https://doi.org/10.1037/0033-2909.103.3.411

Arvidsson, N. (2014). Consumer attitudes on mobile payment services: Results from a proof of concept test. International Journal of Bank Marketing, 32(2), 150-170. https://doi.org/10.1108/IJBM-05-2013-0048

Aulia, S. A., Sukati, I., \& Sulaiman, Z. (2016). A review: Customer perceived value and its dimension. Asian Journal of Social Sciences and Management Studies, 3(2): 150-162. https://doi.org/10.20448/journal.500/2016.3.2/500.2.150.162

Au, Y. A., \& Kauffman, R. J. (2008). The economics of mobile payments: Understanding stakeholder issues for an emerging financial technology application. Electronic Commerce Research and Applications, 7(2), 141-164. https://doi.org/10.1016/j.elerap.2006.12.004

Babin, B. J., Darden, W. R., \& Griffen, M. (1994). Work and/or fun: Measuring hedonic and utilitarian shopping value. Journal of Consumer Research, 20(4), 644-656. https://doi.org/10.1086/209376 
Bagla, R. K., \& Sancheti, V. (2018). Gaps in customer satisfaction with digital wallets: Challenge for sustainability. Journal of Management Development 37(6), 442-451. doi.org/10.1108/JMD-04-2017-0144

Bagozzi, R. P., \& Yi, Y. (1988). On the evaluation of structural equation models. Academy of Marketing Science, 6(1), 74-94.

https://doi.org/10.1007/BF02723327

Bailey, A. A., Pentina, I., Mishra, A. S., \& Mimoun, M. S. B. (2017). Mobile payments adoption by US consumers: An extended TAM. International Journal of Retail \& Distribution Management, 45(6), 626-640.

https://doi.org/10.1108/IJRDM-08-2016-0144

Ballestar, M. T., Sainz, J., \& Torrent-Sellens, J. (2016). Social networks on cashback websites. Psychology \& Marketing, 33(12), 1039-1045. https://doi.org/10.1002/mar.20937

Bhattacherjee, A. (2001a). An empirical analysis of the antecedents of electronic commerce service continuance. Decision Support Systems, 32(2), 201-214. https://doi.org/10.1016/S0167-9236(01)00111-7

Bhattacherjee, A. (2001b). Understanding information systems continuance: An expectation-confirmation model. MIS Quarterly, 25(3), 351-370. https://doi.org/10.2307/3250921

Bitner, M. J., Ostrom, A. L., \& Meuter, M. L. (2002). Implementing successful selfservice technologies. Academy of Management Executive, 16(4), 96-108. https://doi.org/10.5465/ame.2002.8951333

Bitrián, P., Buil, I., \& Catalán, S. (2021). Enhancing user engagement: The role of gamification in mobile apps. Journal of Business Research, 132, 170-185. https://doi.org/10.1016/j.jbusres.2021.04.028

Blattberg, R. C., \& Neslin, S. A. (1990). Sales promotion: Concepts, methods, and strategies. Prentice Hall.

Brown, S. A., \& Venkatesh, V. (2005). A model of adoption of technology in the household: A baseline model test and extension incorporating household life cycle. Management Information Systems Quarterly, 29(3), 399-426. https://doi.org/10.2307/25148690

Buttner, O. B., Florack, A., \& Goritz, A. S. (2015). How shopping orientation influences the effectiveness of monetary and nonmonetary promotions.

European Journal of Marketing, 49(1/2), 170-189. https://doi.org/10.1108/EJM-01-2012-0044

Campbell, L., \& Diamond, W. D. (1990). Framing and sales promotions: The characteristics of a "good deal". Journal of Consumer Marketing, 7(4), 25-31. https://doi.org/10.1108/EUM0000000002586 
Chandon, P., Wansink, B., \& Laurent, G. (2000). A benefit congruency framework of sales promotion effectiveness. Journal of Marketing, 64, 65-81. https://doi.org/10.1509/jmkg.64.4.65.18071

Chawla, D., \& Joshi, H. (2019). Consumer attitude and intention to adopt mobile wallet in India: An empirical study. International Journal of Bank Marketing, 37(7), 1590-1618. https://doi.org/10.1108/IJBM-09-2018-0256

Chemingui, H., \& Ben lallouna, H. (2013). Resistance, motivations, trust and intention to use mobile financial services. International Journal of Bank Marketing, 31(7), 574-592. https://doi.org/10.1108/IJBM-12-2012-0124

Chen, K.-Y., \& Chang, M.-L. (2013). User acceptance of "near field communication' mobile phone service: An investigation based on the 'unified theory of acceptance and use of technology' model. The Service Industries Journal, 33(6), 609-623. https://doi.org/10.1080/02642069.2011.622369

Cheong, J. H., \& Park, M.-C. (2005). Mobile internet acceptance in Korea. Internet Research, 15(2), 125-140. https://doi.org/10.1108/10662240510590324

Chin, A. G., Harris, M. A., \& Brookshire, R. (2020). An empirical investigation of intent to adopt mobile payment systems using a trust-based extended valence framework. Information Systems Frontiers. Advance online publication. https://doi.org/10.1007/s10796-020-10080-x

Chin, W. W., \& Newsted, P. R. (1999). Structural equation modeling analysis with small samples using partial least squares. In R. Hoyle (Ed.), Statistical strategies for small sample research (pp. 307 - 341). Sage Publications.

Chiu, C.-M., Wang, E. T. G., Fang, Y.-H., \& Huang, H.-Y. (2014). Understanding customers' repeat purchase intentions in $\mathrm{B} 2 \mathrm{C}$ e-commerce: The roles of utilitarian value, hedonic value and perceived risk. Information Systems Journal, 24(1), 85-114. https://doi.org/10.1111/j.1365-2575.2012.00407.x

Chong, A. Y.-L., Chan, F. T. S., \& Ooi, K.-B. (2012). Predicting consumer decisions to adopt mobile commerce: Cross country empirical examination between China and Malaysia. Decision Support Systems, 53(1), 34--43. https://doi.org/10.1016/j.dss.2011.12.001

Chun, H., Lee, H., \& Kim, D. (2012). The integrated model of smartphone adoption: Hedonic and utilitarian value perceptions of smartphones among Korean college students. Cyberpsychology, Behavior and Social Networking, 15(9), 473-479. https://doi.org/10.1089/cyber.2012.0140

Common Service Centres Scheme (2021). Digital India. https://csc.gov.in/digitalIndia

Competition Commission of India (2020). Market study on e-Commerce in India: Key findings and observations. https://www.cci.gov.in/node/4637 
Cruz, P., Neto, L. B. F., Muñoz-Gallego, P., \& Laukkanen, T. (2010). Mobile banking rollout in emerging markets: Evidence from Brazil. International Journal of Bank Marketing, 28(5), 342-371. https://doi.org/10.1108/02652321011064881

Dabholkar, P.A, \& Bagozzi, R. (2002). An attitudinal model of technology-based self-service: Moderating effects of consumer traits and situational factors. Journal of the Academy of Marketing Science, 30(3), 184-201. https://doi.org/10.1177/0092070302303001

Davis, F. D., Bagozzi, R. P., \& Warshaw, P.R. (1992). Extrinsic and intrinsic motivation to use computers in the workplace. Journal of Applied Social Psychology, 22(14), 1111-1132. https://doi.org/10.1111/j.15591816.1992.tb00945.x

Deng, L., Turner, D. E., Gehling, R., \& Prince, B. (2010). User experience, satisfaction, and continual usage intention of IT. European Journal of Information Systems, 19(1), 60-75. https://doi.org/10.1057/ejis.2009.50

do Valle, P. O., \& Assaker, G. (2016). Using partial least squares structural equation modeling in tourism research: A review of past research and recommendations for future applications. Journal of Travel Research, 55(6), 695-708. https://doi.org/10.1177/0047287515569779

Featherman, M. S., \& Pavlou, P. A. (2003). Predicting e-Services adoption: A perceived risk facets perspective. International Journal of Human-Computer Studies 59(4),451-474. https://doi.org/10.1016/S1071-5819(03)00111-3

Ferreira J., \& Perry M. (2019). From transactions to interactions: Social considerations for digital money. In T. Lynn, J. Mooney, P. Rosati, \& M. Cummins (Eds.), Disrupting finance. Palgrave studies in digital business \& enabling technologies (pp. 121-133). Palgrave. https://doi.org/10.1007/978-3030-02330-0_8

Fornell, C. G., \& Larcker, D. F. (1981). Evaluating structural equation models with unobservable variables and measurement error. Journal of Marketing Research, 18(1), 39-50. https://doi.org/10.1177/002224378101800104

Gao, L., \& Waechter, K. A. (2017). Examining the role of initial trust in user adoption of mobile payment services: An empirical investigation. Information Systems Frontiers, 19(3), 525-548. https://doi.org/10.1007/s10796-015-9611-0

Gefen, D., Straub, D., \& Boudreau, M. C. (2000). Structural equation modeling and regression: Guidelines for research practice. Communications of the Association for Information Systems, 4(Article 7). https://doi.org/10.17705/1CAIS.00407

Goodwin, N. R. (1996). Economic meanings of trust and responsibility. The University of Michigan Press. 
Groß, M. (2016). Impediments to mobile shopping continued usage intention: A trust-risk-relationship. Journal of Retailing and Consumer Services, 33, 109119. https://doi.org/10.1016/j.jretconser.2016.08.013

Hair, J. F., Jr., Anderson, R. E., Tatham, R. L., \& Black, W. C. (1998). Multivariate data analysis. Prentice-Hall.

Hair, J. F., Jr., Black, W. C., Babin, B. J., \& Anderson, R. E. (2010). Multivariate data analysis (7th ed.). Prentice Hall.

Hair, J., Hollingsworth, C. L., Randolph, A. B., \& Chong, A. Y. L. (2017), An updated and expanded assessment of PLS-SEM in information systems research. Industrial Management \& Data Systems, 117(3), 442-458. https://doi.org/10.1108/IMDS-04-2016-0130

Hair, J. F., Sarstedt, M., Pieper, T. M., \& Ringle, C. M. (2012). The use of partial least squares structural equation modeling in strategic management research: A review of past practices and recommendations for future applications. Long Range Planning, 45(5-6), 320-340. https://doi.org/10.1016/j.lrp.2012.09.008

Hair, J. F., Sarstedt, M., Ringle, C. M., \& Mena, J. A. (2012). An assessment of the use of partial least squares structural equation modeling in marketing research. Journal of the Academy of Marketing Science, 40(3), 414-433. https://doi.org/10.1007/s11747-011-0261-6

Hanafizadeh, P., Behboudi, M., Koshksaray, A. A., \& Tabar, M. J. S. (2014). Mobile-banking adoption by Iranian bank clients. Telematics and Informatics, 31(1), 62-78. https://doi.org/10.1016/j.tele.2012.11.001

Hofacker, C. F., De Ruyter, K., Lurie, N. H., Manchanda, P., \& Donaldson, J. (2016). Gamification and mobile marketing effectiveness. Journal of Interactive Marketing, 34, 25-36. https://doi.org/10.1016/j.intmar.2016.03.001

Holbrook, M. B. (1999). Introduction. In M. B. Holbrook (Ed.), Consumer value: a framework for analysis and research (1st ed.) (pp. 1-28). Routledge.

Hsiao, C.-H., Chang, J.-J., \& Tang, K.-Y. (2016). Exploring the influential factors in continuance usage of mobile social apps: Satisfaction, habit, and customer value perspectives. Telematics and Informatics, 33(2),342-355. https://doi.org/10.1016/j.tele.2015.08.014

Igbaria, M., Schiffman, S., \& Wieckowski, T. (1995). The respective roles of perceived usefulness and perceived fun in the acceptance of microcomputer technology. Behaviour and Information Technology, 13(6), 349-361. https://doi.org/10.1080/01449299408914616

India Brand Equity Foundation (2021). Indian retail industry report, https://www.ibef.org/industry/retail-india.aspx

Islam Z., Kim Cheng Low, P., \& Hasan, I. (2013). Intention to use advanced mobile phone services (AMPS). Management Decision, 51(4), 824-838.

https://doi.org/10.1108/00251741311326590 
Jones, M. A., Reynolds, K. E., \& Arnold, M. J. (2006). Hedonic and utilitarian shopping value: Investigating differential effects on retail outcomes. Journal of Business Research, 59(9), 974-981.

https://doi.org/10.1016/j.jbusres.2006.03.006

Kanagasabai, B., \& Aggarwal, V. (2020). The mediating role of risk tolerance in the relationship between financial literacy and investment performance. Colombo Business Journal, 11(1), 83-104. https://doi.org/10.4038/cbj.v11i1.58

Keith, M. J., Babb, J. S., Lowry, P. B., Furner, C. P., \& Abdullat, A. (2015). The role of mobile-computing self-efficacy in consumer information disclosure. Information Systems Journal, 25(6), 637- 667. https://doi.org/10.1111/isj.12082.

Kim, C., Zhao, W., \& Yang, K. H. (2008). An empirical study on the integrated framework of e-CRM in online shopping: Evaluating the relationships among perceived value, satisfaction, and trust based on customers' perspectives. Journal of Electronic Commerce in Organizations, 6(3), 1-19. https://doi.org/10.4018/jeco.2008070101

Kim, D. J., Cho, B., \& Rao, H. R. (2000). Effects of consumer lifestyles on purchasing behavior on the internet: A conceptual framework and empirical validation, ICIS Proceedings - 2000 (pp. 688-695). Association for Information Systems. https://aisel.aisnet.org/icis2000/76/

Kim, H.-W., Chan, H. C., \& Gupta, S. (2007). Value-based adoption of mobile internet: An empirical investigation. Decision Support Systems, 43(1), 111-126. https://doi.org/10.1016/j.dss.2005.05.009

Kleijnen, M., de Ruyter, K., \& Wetzels, M. (2007). An assessment of value creation in mobile service delivery and the moderating role of time consciousness. Journal of Retailing, 83 (1), 33-46. https://doi.org/10.1016/j.jretai.2006.10.004 Kock, N. (2012). WarpPLS 5.0 user manual. ScriptWarp Systems.

Koenig-Lewis, N., Marquet, M., Palmer, A., \& Zhao, A. L. (2015). Enjoyment and social influence: Predicting mobile payment adoption. The Service Industries Journal, 35(10), 537-554. https://doi.org/10.1080/02642069.2015.1043278

Koenig-Lewis, N., Palmer, A., \& Moll, A. (2010). Predicting young consumers' take up of mobile banking services. International Journal of Bank Marketing, 28(5), 410-432. https://doi.org/10.1108/02652321011064917

Lankton, N. K., McKnight, D. H., \& Thatcher, J. B. (2012). The moderating effects of privacy restrictiveness and experience on trusting beliefs and habit: An empirical test of intention to continue using a social networking website. IEEE Transactions on Engineering Management, 59(4) 654-665.

https://ieeexplore.ieee.org/document/6134647

Larivière, B., Joosten, H., Malthouse, E. C., Birgelen, M. V., Aksoy, P., Kunz, W. H., \& Huang, M.-H. (2013). Value fusion: The blending of consumer and firm 
value in the distinct context of mobile technologies and social media. Journal of Service Management, 24(3), 268-293. https://doi.org/10.1108/09564231311326996

Lee, S. A. (2018). M-servicescape: Effects of the hotel mobile app servicescape preferences on customer response. Journal of Hospitality and Tourism Technology, 9(2), 172-187. https://doi.org/10.1108/JHTT-08-2017-0066

Lee, W.-K. (2014). The temporal relationships among habit, intention and IS uses. Computers in Human Behavior, 32, 54-60. https://doi.org/10.1016/j.chb.2013.11.010

Limayem, M., Hirt, S. G., \& Cheung, C. M. K. (2007). How habit limits the predictive power of intention: The case of information systems continuance. MIS Quarterly, 31(4), 705-737. https://doi.org/10.2307/25148817

Lu,Y., Yang, S., Chau, P. Y. K., \& Cao, Y. (2011). Dynamics between the trust transfer process and intention to use mobile payment services: A cross environment perspective. Information \& Management, 48(8), 393-403. https://doi.org/10.1016/j.im.2011.09.006

Madan, K., \& Yadav, R. (2016). Behavioural intention to adopt mobile wallet: A developing country perspective. Journal of Indian Business Research, 8(3), 227-244. https://doi.org/10.1108/JIBR-10-2015-0112

Magro, M. J., Ryan, S. D., \& Prybutok, V. R. (2013). The social network application post-adoptive use model (SNAPUM): A model examining social capital and other critical factors affecting the post-adoptive use of Facebook. Informing Science, 16, 37-69. https://doi.org/10.28945/1777

Mallat, N. (2007). Exploring consumer adoption of mobile payments - A qualitative study. Journal of Strategic Information Systems, 16(4), 413-432. https://doi.org/10.1016/j.jsis.2007.08.001

Matemba, E. D., \& Li, G. (2018). Consumers' willingness to adopt and use WeChat wallet: An empirical study in South Africa. Technology in Society, 53, 55-68. https://doi.org/10.1016/j.techsoc.2017.12.001

Mehra, A., Paul, J., \& Kaurav, R. P. S. (2020). Determinants of mobile apps adoption among young adults: Theoretical extension and analysis. Journal of Marketing Communications. Advance online publication. https://doi.org/10.1080/13527266.2020.1725780

Merritt, C. (2011). Mobile money transfer services: The next phase in the evolution of person-to-person payments. Journal of Payments Strategy \& Systems, 5(2), $143-160$.

Mou, J., Cohen, J., Dou, Y., \& Zhang B. (2017). Predicting buyers' repurchase intentions in cross-border e-Commerce: A valence framework perspective. Proceedings of the 25th European Conference on Information Systems (ECIS) - 
2017 (pp. 2382-2394). Association for Information Systems.

https://aisel.aisnet.org/ecis2017_rp/151/

Nataraj, B., \& Rajendran, R. (2018). Impact of relationship quality on customer retention - A study with reference to retail banking in India. International Journal of Business and Information, 13(1), 93-117. https://doi.org/10.6702/ijbi.201803_13(1).0004

Nysveen, H., Pedersen, P. E., \& Thorbjørnsen, H. (2005). Intentions to use mobile services: Antecedents and cross-service comparisons. Journal of the Academy of Marketing Science, 33(3), 330-346.

https://doi.org/10.1177/0092070305276149

Oliveira, T., Thomas, M., Baptista, G., \& Campos, F. (2016). Mobile payment: Understanding the determinants of customer adoption and intention to recommend the technology. Computers in Human Behavior, 61, 404-414. https://doi.org/10.1016/j.chb.2016.03.030

Overby, J. W., \& Lee, E.-J. (2006). The effects of utilitarian and hedonic online shopping value on consumer preference and intentions. Journal of Business Research, 59(10-11), 1160-1166. https://doi.org/10.1016/j.jbusres.2006.03.008

Ozturk, A. B., Bilgihan, A., Salehi-Esfahani, S., \& Hua, N. (2017). Understanding the mobile payment technology acceptance based on valence theory: A case of restaurant transactions. International Journal of Contemporary Hospitality Management, 29(8), 2027-2049. https://doi.org/10.1108/IJCHM-04-2016-0192

Ozturk, A. B., Nusair, K., Okumus, F., \& Hua, N. (2016). The role of utilitarian and hedonic values on users' continued usage intention in a mobile hotel booking environment. International Journal of Hospitality Management, 57, 106-115. https://doi.org/10.1016/j.ijhm.2016.06.007

Park, J. \& Yang, S. (2006). The moderating role of consumer trust and experiences: Value driven usage of mobile technology. International Journal of Mobile Marketing, 1(2), 24-32.

Peter, J. P., \& Tarpey L. X., Sr. (1975). A comparative analysis of three consumer decision strategies. Journal of Consumer Research, 2(1), 29-37.

Podsakoff, P. M., MacKenzie, S. B., Lee, J. Y., \& Podsakoff, N. P. (2003). Common method biases in behavioural research: A critical review of the literature and recommended remedies. Journal of Applied Psychology, 88(5), 879-903. https://doi.org/10.1037/0021-9010.88.5.879

Pura, M. (2005). Linking perceived value and loyalty in location-based mobile services. Managing Service Quality: An International Journal, 15(6), 509-538. https://doi.org/10.1108/09604520510634005

Reichheld, F. F., \& Schefter, P. (2000, July-August). E-loyalty: Your secret weapon on the Web. Harvard Business Review, 78(4), 105-113. 
Reserve Bank of India. (2019). RBI bulletin.

Richter, N. F., Cepeda Carrión, G. A., Roldán, J. L., \& Ringle, C. M. (2016).

European management research using partial least squares structural equation modeling (PLS-SEM) [Editorial]. European Management Journal, 34(6), 589597. https://doi.org/10.1016/j.emj.2016.08.001

Richter, N. F., Sinkovics, R. R., Ringle, C. M., \& Schlägel, C. (2016). A critical look at the use of SEM in international business research. International Marketing Review, 33(3) 376-404. https://doi.org/10.1108/IMR-04-2014-0148

Rigdon, E. E. (2016). Choosing PLS path modeling as analytical method in European management research: a realist perspective. European Management Journal, 34(6), 598-605. https://doi.org/10.1016/j.emj.2016.05.006

Riquelme, H. E., \& Rios, R. E. (2010). The moderating effect of gender in the adoption of mobile banking. International Journal of Bank Marketing, 28(5), 328-341. https://doi.org/10.1108/02652321011064872

Sarstedt, M., Hair, J. F., Ringle, C. M., Thiele, K. O., \& Gudergan, S. P. (2016). Estimation issues with PLS and CBSEM: Where the bias lies! Journal of Business Research, 69(10), 3998-4010. https://doi.org/10.1016/j.jbusres.2016.06.007

Shankar, A., \& Datta, B., (2018) Factors affecting mobile payment adoption intention: An Indian perspective. Global Business Review 19(3), S72-S89. https://doi.org/10.1177/0972150918757870

Shaw, N. (2014). The mediating influence of trust in the adoption of the mobile wallet. Journal of Retailing and Consumer Services, 21(4), 449-459. https://doi.org/10.1016/j.jretconser.2014.03.008

Shin, D.-H. (2009). Towards an understanding of the consumer acceptance of mobile wallet. Computers in Human Behavior, 25(6), 1343-1354. https://doi.org/10.1016/j.chb.2009.06.001

Shmueli, G., Ray, S., Estrada, J. M. V., \& Chatla, S. B. (2016). The elephant in the room: Predictive performance of PLS models. Journal of Business Research, 69(10), 4552-4564. https://doi.org/10.1016/j.jbusres.2016.03.049

Slade, E. L., Dwivedi, Y. K., Piercy, N. C., \& Williams, M. D. (2015). Modeling consumers' adoption intentions of remote mobile payments in the United Kingdom: Extending UTAUT with innovativeness, risk, and trust. Psychology \& Marketing, 32(8), 860-873. https://doi.org/10.1002/mar.20823

Sun, Y., Liu, L., Peng, X., Dong, Y., \& Barnes, S. J. (2014). Understanding Chinese users' continuance intention toward online social networks: An integrative theoretical model. Electronic Markets, 24(1), 57-66.

https://doi.org/10.1007/s12525-013-0131-9 
Sweeney, J. C., \& Soutar, G. N. (2001). Consumer perceived value: The development of a multiple item scale. Journal of Retailing, 77(2), 203-220. https://doi.org/10.1016/S0022-4359(01)00041-0

Tenenhaus, M., Esposito Vinzi, V., Chatelin, Y.-M., \& Lauro, C. (2005). PLS path modeling. Computational Statistics \& Data Analysis, 48(1), 159-205. https://doi.org/10.1016/j.csda.2004.03.005

Teng, H.-J., Ni, J.-J., \& Chen, H.-H. (2018). Relationship between e-servicescape and purchase intention among heavy and light internet users. Internet Research, 28(2), 333-350. https://doi.org/10.1108/IntR-10-2016-0303

Thakur, R. (2016). Understanding customer engagement and loyalty: A case of mobile devices for shopping. Journal of Retailing and Consumer Services, 32, 151-163. https://doi.org/10.1016/j.jretconser.2016.06.004

Thakur, R., \& Srivastava, M. (2014). Adoption readiness, personal innovativeness, perceived risk and usage intention across customer groups for mobile payment services in India. Internet Research, 24(3), 369-392. https://doi.org/10.1108/IntR-12-2012-0244

Tsu Wei, T., Marthandan, G., Yee-Loong Chong, A., Ooi, K.-B., \& Arumugam, S. (2009). What drives Malaysian m-commerce? An empirical analysis. Industrial Management \& Data Systems, 109(3), 370-388.

https://doi.org/10.1108/02635570910939399

Vana, P., Lambrecht, A., \& Bertini, M. (2018). Cashback is cash forward: Delaying a discount to entice future spending. Journal of Marketing Research, 55(6), 852-868. https://doi.org/10.1177/0022243718811853

Venkatesh, V., \& Davis, F. D. (2000). A theoretical extension of the technology acceptance model: Four longitudinal field studies. Management Science, 46(2), 186-204. https://doi.org/10.1287/mnsc.46.2.186.11926

Venkatesh, V., Thong, J. Y. L., \& Xu, X. (2012). Consumer acceptance and use of information technology: Extending the unified theory of acceptance and use of technology. MIS Quarterly, 36(1), 157-178. https://doi.org/10.2307/41410412

Wong, C. H., Lee, H. S., Chua, B. H., Chai, B. H., \& Tan Han, G. W. (2012). Predicting the consumers' intention to adopt mobile shopping: An emerging market perspective. International Journal of Network and Mobile Technologies, 3(3). 24-39. http://ur.aeu.edu.my/510/

Wu, J.-H., \& Wang, S.-C. (2005). What drives mobile commerce? An empirical evaluation of the revised technology acceptance model. Information \& Management, 42(5), 719-729. https://doi.org/10.1016/j.im.2004.07.001

Yang, H. (2013). Young American consumers' online privacy concerns, trust, risk, social media use, and regulatory support. Journal of New Communications Research, 5(1), 1-30. 
Yang, K. (2010). Determinants of US consumer mobile shopping services adoption: Implications for designing mobile shopping services. Journal of Consumer Marketing, 27(3), 262-270. https://doi.org/10.1108/07363761011038338

Yang, K., \& Lee, H.-J., (2010). Gender differences in using mobile data services: Utilitarian and hedonic value approaches. Journal of Research in Interactive Marketing, 4(2), 142-156. https://doi.org/10.1108/17505931011051678

Yang, S., Liu, Y., Gupta, S., Cao, Y., \& Zhang, R. (2012). Mobile payment service adoption across time: An empirical study of the effects of behavioural beliefs, social influences, and personal traits. Computers in Human Behavior, 27(1), 129-142. https://doi.org/10.1016/j.chb.2011.08.019

Yang, Y., Liu, Y., Li, H., \& Yu, B. (2015). Understanding perceived risks in mobile payment acceptance. Industrial Management \& Data Systems 115(2), 253-269. https://doi.org/10.1108/IMDS-08-2014-0243

Young, R. A., \& Kent, A. T. (1985). Using the theory of reasoned action to improve the understanding of recreation behaviour. Journal of Leisure Research, 17(2), 90-106. https://doi.org/10.1080/00222216.1985.11969618

Zheng, Y., Zhao, K., \& Stylianou, A. (2013). The impacts of information quality and system quality on users' continuance intention in information-exchange virtual communities: An empirical investigation. Decision Support Systems, 56(4), 513-524. https://doi.org/10.1016/j.dss.2012.11.008

Zhou, T. (2013). An empirical examination of continuance intention of mobile payment services. Decision Support Systems, 54(2), 1085-1091. https://doi.org/10.1016/j.dss.2012.10.034

Zhou, T., Lu, Y., \& Wang, B. (2010). Integrating TTF and UTAUT to explain mobile bankinguser adoption. Computers in Human Behavior, 26(4), 760-767. https://doi.org/10.1016/j.chb.2010.01.013

Zhou, W., Tsiga, Z., Li, B., Zheng, S., \& Jiang, S. (2018). What influence users' efinance continuance intention? The moderating role of trust. Industrial Management and Data Systems, 118(8), 1647-1670. https://doi.org/10.1108/IMDS-12-2017-0602

Zhu, D. H., \& Chang, Y. P. (2014). Understanding motivations for continuance intention of online communities in China: A comparison of active users of social networking sites and virtual communities. Information Development 30(2), 172-180. https://doi.org/10.1177/0266666913482597

Zolkepli, I. A., Mukhiar, S. N. S., \& Tan, C. (2020). Mobile consumer behaviour on apps usage: The effects of perceived values, rating, and cost. Journal of Marketing Communications. Advance online publication. https://doi.org/10.1080/13527266.2020.1749108 


\section{Appendix :1 Measurement Items Used in the Study}

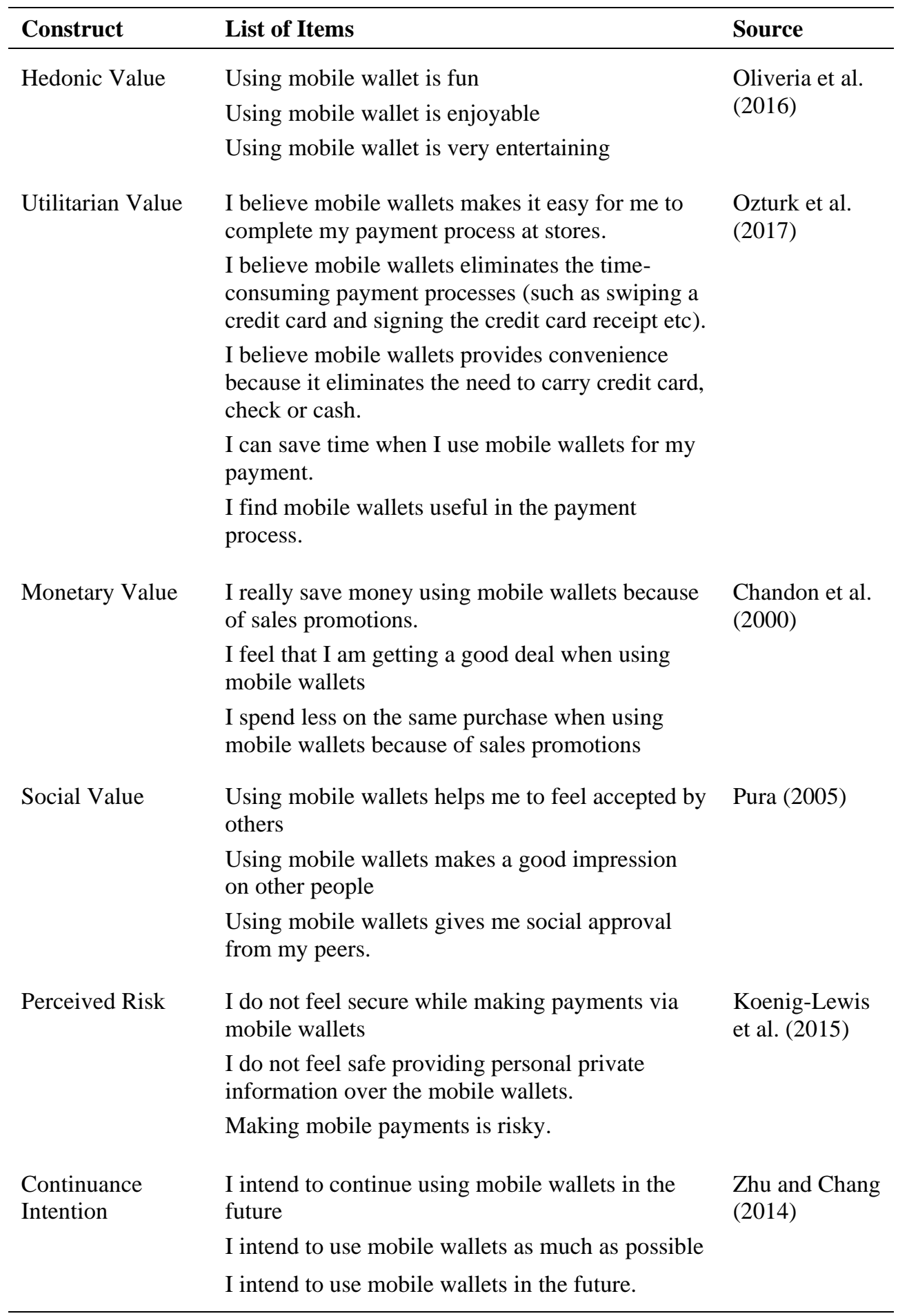

